\title{
ETHNIC MINORITY PUPILS IN INDONESIAN SCHOOLS: SOME TRENDS IN OVER-REPRESENTATION OF MINORITY PUPILS IN SPECIAL EDUCATIONAL PROGRAMMES AT THE VOCATIONAL
}

\author{
Soetyono Iskandar \\ soet_54mks@yahoo.com
}

\begin{abstract}
The way categories, labels, and taxonomies are used depends upon national ideologies and nationally specific conceptions of citizenship and normality. Ethnicity, differences, disability and deviance are social constructions. Underachievement or overachievement in social (cognitive) performance or overrepresentation in special educational placements of certain groups of students is as much the product of categorisation or definitional processes as it is the workings of institutional procedures, patterns, and intransigence. In particular (Vocational), schools' inability to accommodate difference and diversity causes exclusion and alienation. Globalisation and hegemonic neo-liberal ideology make it difficult to create a genuinely inclusive society, to produce complete citizens, and to promote equity. This study analyses the placement of ethnic minority students in special education programmes. It begins with a review of empirical reports that problematise the phenomenon of overrepresentation of students with immigrant background in special schools for intellectually disabled students. The analysis that follows is conducted through the prism of a number of perspectives, including sociocultural/historical theory, the inclusive education movement, multicultural education, and critical pedagogical theories. While there is no evidence to suggest that such overrepresentation is nationwide, the phenomenon can be identified in large cities where there are concentrations of immigrants. Analysis demonstrates that the problem is related to, among other factors, unreliable assessment procedures and criteria for referral and placement; lack of culturally sensitive diagnostic tools; the static nature of tests, including embedded cultural bias; sociocultural problems, family factors, and language problems; lack of parental participation in decision-making; power differentials between parents and school authorities; institutional intransigence and prejudices; and large resource inequalities that run along lines of race and class.
\end{abstract}

Keywords: Ethnicity, differences, disability and deviance are social constructions.

\section{Introduction}

Construction and Deconstruction of Ethnicity

Social science research of the last two decades strongly points to a more social construction view of difference and diversity (Gergen, 2001; Hacking, 1999). This view of diversity, disability, and difference is not just a humanistic approach, but is, rather, grounded on valid research and evidence that lends support to the conclusion that conceptions of differences are deeply entrenched in language use, discourse, history, context, culture, and ideological forces and power relations (Gergen, 2001; Thomas \& Loxley, 2001). With regard to this, one good example is the way Great Britain and France define/understand ethnicity and how that conception is related to official taxonomies, educational policy, and practices. These are, in particular, linked with nationally specific conceptions of citizenship. Based on ethnographic research and a closer examination of the relevant research carried out on the two aforementioned countries, Raveaud (2003) revealed that the treatment of immigrants and their descendants is related to national ideology. The UK through its Multicultural Model uses typologies and classifications related to ethnic minority, colour, and race, whereas France avoids these terms and prefer to use the term immigrants or nationality as a marker (Raveaud, 2003; also van Zanten, 1997). The French Republican Model refuses to recognise the existence of majorities and minorities (van Zanten, 1997). Whether or not the French indifference to difference/diversity or the British emphasis on multiculturalism, diversity, and difference is the appropriate measure remains to be seen and is hotly debateable on both sides of the Channel. As two big European nations with a long history of colonialism and immigration, it is imperative that we use their experiences as a point of departure for our analysis of the Swedish experience here. Sweden appears to find itself somewhere in between these two countries' ideological spectrums. It explicitly adopts multiculturalism and cultural diversity in an atmosphere of mutual tolerance; however, terms such as ethnicity, colour, and race are obscure both in official taxonomies, educational policies, and practices in schools. In fact, it is during these 10 years that the terms, in particular the term ethnicity, began to be widely used in academia as well as in the media. The most common typologies/categories 
used to refer to minority ethnic groups are immigrants, students with immigrant background (elever), and foreigners.

While the concept of ethnicity is not new, its widespread use in Swedish social and educational policy discourse is a very recent phenomenon. In that sense there is some similarity with the French model. Accordingly, the research landscape, taxonomies, discourses at different levels, and political intentions are shifting rapidly with regard to policies aimed at the integration and inclusion of immigrant students in the mainstream educational process. A good example in this domain is the reasons given for the underachievement or overrepresentation of ethnic minority students in special educational placements. In a recent report issued by the Swedish school authority (Skolverket, 2004), it is indicated that most of the academic difficulties ascribed to immigrants can be attributed to socioeconomic factors. When such factors are being controlled for, most of the group differences are eliminated.

It is interesting to note the similarities of findings that came out of the educational authorities in France (Ministry of Education statistics department, 1995 in Vallet and Caille, 1995) and the diametrically opposite conclusions drawn from the British studies (see, e.g., Gillborn \& Youdell 2000; Gillborn \& Mirza, 2000; Gillborn \& Gipps, 1996; OFSTED, 1999) about the causal factors attributed to underachievement of ethnic minority students, which emphasised the significant role ethnic belonging plays and that social class accounts for only part of educational inequality. The above three studies were conducted by researchers financed by their respective ministries/authorities of education. It is safe to conclude that Sweden appears to be entangled along this continuum between constructing ethnic differences and deconstructing ethnic differences to an extent considering it to be a social artefact as in the case of French Republican traditions. In this paper by leaning on the use of such terms as ethnicity, difference, and diversity, I am embarking on a social construction philosophical flight. The above introduction is simply to illustrate how national ideologies and research directions influence each other and that both are social constructions that, in turn, shape the conceptualization of difference.

In this paper, ethnic minority pupils and pupils with immigrant background are used interchangeably. Actually, most of the studies analysed here, when referring to overrepresentation of ethnic minority pupils in special educational placements, usually meant those immigrants who had migrated to Sweden within the past 20 years. In many cases, these pupils were born outside Sweden and can be termed as new arrivals. (It is notable that Sweden has five National Minorities: Jews, Roma,
Sami (also an indigenous people), Swedish Finns and Tornedalers. The historical minority languages are: Yiddish, Romany Chib (all varieties), Sami (all varieties), Finnish, and Meänkiel (Tornedal Finnish).

\section{Current Swedish Educational Policies and Their Contradictory Messages}

The decrees, statutes, and policies that have evolved in the early 90s in Sweden are characterised by contradictory messages related to conception of knowledge, social justice and equity and equality issues. This has also had an effect on student achievement profiles and marginalized a large segment of the student population from ordinary educational settings. This is not an accidental phenomenon. It is part and parcel of global phenomena in our late modernity (Bauman, 1992), high modernity (Giddens, 1990) and /or late capitalism that is deeply entrenched with values of effectivity, competition, standardisation, freedom of choice, and increasingly individualist and elitist culture. The notion of special needs is intimately linked to the rise of the worldwide inclusive education movement, in Sweden named A school for all in the 1980s. Paradoxically, in the footsteps of the introduction of inclusive education, the number of pupils labelled as having special needs increased dramatically (Persson, 1998; Rosenqvist, 2007; Skolverket, 2002). Teachers found themselves incapable of dealing with pupil diversity in the classroom and to meet everyone's individual needs. This has often been regarded as schools' failure to meet the diverse needs of pupils, manifesting itself in resignation and distress among teachers and pupils not achieving set targets. However, it might be questioned whether the inclusive school is anything more than a structural or organizational phenomenon resting upon political rhetoric with little or no anchorage in public policy (Barton, 1997; Emanuelsson, Haug, \& Persson, 2005; Nilholm \& Björck-Åkesson, 2007).

This fragmentation of educational policymaking has excluded in particular the already vulnerable groups such as the disabled, ethnic minority students, and the socially disadvantaged segments of the population. Bauman (1992, 1998, 2001) argues eloquently that globalisation has produced a shift from social rights to competition, productivity, standardisation, and efficiency, and a shift from public to private and from social responsibility to individual (or family) responsibility. As a process, globalisation is not linear, but contradictory and contested. Its impacts are unequal and differ on the basis of regions, classes, and people. The neo-liberal economy is dominating the world especially after the end of the cold war, and its particular form of capitalism is characterised by deregulating markets, reducing or changing the role of the state and most importantly, 
reducing social expenditure, including expenditure on education. This phenomenon has also been witnessed in the past 15 years even in Sweden in tandem with rising unemployment, issues of security, alienation, marginalisation and exclusion, creating a discourse of resentment along the lines of them versus us. I presume, on the basis of a large number of indicators, that over the next decade Swedish society will become increasingly multiethnic and multilingual and the number of disadvantaged children will substantially increase. An estimated $20 \%$ of the Swedish population has an immigrant background. It is expected that the demographic landscape in the year 2020 is that $30 \%$ of all working age individuals in Sweden will have had their roots outside of Sweden (Leijon \& Omanovic, 2001; Statistics Sweden, 2004).

Many, many students are at greater risk of needing special education services when they are poor or of a minority race or language. The need for addressing and reviewing scientific and methodological problems explaining overrepresentation and educational outcome differences related to race, ethnicity, socioeconomic status becomes imperative. (The rule of thumb is that a group is considered overrepresented if their enrolment in special education is equal to or greater than $10 \%$ of their proportion in general education; CEEP, 2004, Nov.).

Problems that need to be addressed will include (a) defining terms with precision and accuracy, (b) examining epistemological considerations such as ethnic/race categorisation and explaining group differences, and (c) developing unbiased research methodology and procedures for sampling, instrumentation, and measurement (see Obiakor, 1994; Obiakor \& Utley, 1997).

\section{Theoretical Perspectives and Research Genres}

This analysis is anchored within a twopronged theoretical perspective. The first is the perspective of inclusive education within discourses on special educational research and provisions (Clark, Dyson, \& Millward, 1995; Thomas \& Loxley, 2001) and the second is a sociocultural perspective within Vygotskian as well as neoVygotskian tradition. In the first vein, the last two decades of research shows not only the lack of well founded and sound theories in special education (see, e.g., Clark et al., 1995; Emanuelsson, 1998, 2000a, 2000b; Persson, 1998; Skrtic, 1991, 1995) but also the crisis in special education knowledge. In particular, the overrepresentation of minority pupils in special educational programmes has been a cause for concern and debateable issue. It has been noted in a number of countries that ethnic minority groups are disproportionately represented in special classes and schools. (See Berhanu, 2001; Brady, Manni, \& Winnikur, 1983; Coard, 1971;
Gillborn, 1990; Losen \& Orfield, 2002; Dyson \& Gallannaugh, 2008). Also some Swedish reports, e.g., Bel Habib, 2001; Bloom, 1999; Hahne Lundström, 2001; Lahdenperä, 1977; Skolverket, 1998, 2003, 2005a; SOU, 1977, and a number of student theses). (Although, in the case of Sweden, a very recent study conducted by Jerry Rosenqvist and associates (2007), commissioned by The Swedish Institute for Special Needs Education, has not supported the hypothesis that there is overrepresentation at a national level).

Although these studies show that marginalized, subaltern, and ethnic minority groups are overrepresented in those special services all out of proportion to their number, they do not tell us much about the possible causal factors that can be accountable for their lag in the regular school system. One purpose of this article is, therefore, to elucidate the process of special educational placement and to highlight the major causal factors that may be responsible for the observed overrepresentation based on some experiences from Sweden. For the purpose of this study, the term special educational placement or programme refers to schools and classrooms for students with severe learning disabilities (särskolan). The paper also discusses the paradox and dilemmas that characterize the changing identities of special education in the light of the current catchy phrase inclusive education.

Most of the above studies and a large number of other similar studies indicated the significance of inclusive education, cultural diversity and intercultural education as central themes in the educational arena. As cultural pluralism becomes increasingly a social reality, education authorities are grappling with the new phenomena to reconcile the conventional monolithic educational approach with the emerging pluralistic trends - cultural, racial and ethnic diversity - that require accommodation to the cultural norms of pluralism. The conflicts between the culture of the school and the culture of the home, minority-majority relationships, values, identity matters, and language and cognitive styles and strategies have become a new focus of attention (Berhanu, 2001, 2005a,b, 2006). Artiles (2003) recently noted that minority overrepresentation and inclusion pose important challenges to special educators understandings of culture, the role of culture in visions of disability, and the creation of a research ethos that is mindful of cultural differences (p. 165).

The second perspective applied in this study is a combination of the sociocultural-historical theory of cognitive development (Vygotsky, 1934, 1978; Valsiner \& Van den Veer, 2000) and the social theory of learning model (Wenger, 1998). Both perspectives take social interactions into account and focus on the structure of activities as historically constituted; and meaning, practice, 
community, and identity are treated as major components necessary to characterise social participation as a process of learning and knowing. The particular relationship between culture/ethnicity, special education, exclusion/control, feeling of rootlessness, and family disintegration is complex and deserves close scrutiny and thoughtful analysis. The issue of over identification of minority students for special education is not a new concern and has been discussed in special education literature for some time. However, it is important to remember in the context of what we are discussing here that many of the problems with special education are outgrowths of larger problems with education generally and must be treated as such. It is no coincidence that many of the communities struggling with special education challenges are the same communities plagued by general education deficiencies.

Disproportionality in special education placements occurs through a process of social construction by which decisions about disability and its appropriate treatments are negotiated according to official and unofficial beliefs and practices. To discover what lies behind disproportionality, research must use methods that can document the social processes that lead to it. Statistical analysis can be used to provide a powerful teasing out of the variables that are associated with disproportionality (see Losen \& Orfield, 2002). Oswald, Coutinho, and Best (2000) proposed two general hypothesis on the phenomenon of disproportionality; the first one being tied to real differences in socioeconomic outcomes between social groups. That some groups (or minority students) are deeply disadvantaged (in social and economic experiences), marginalized, susceptible to diseases, and disabilities; and the second hypothesis is that a significant portion of the over-representation problem may be a function of inappropriate interpretation of ethnic and cultural differences as disabilities (p. 2). As we see later in the paper there is sound evidence to support the hypothesis (See also Dyson \& Gallannaugh, 2008 for similar observation in England).

The Phenomenon of Over-Representation of Minority Pupils in Special Educational Placements

One in five compulsory school pupils in Sweden are judged to be in need of special needs education according to Persson (2002). At the same time, the number of pupils enrolled in special schools for the intellectually disabled (särskolan) has increased from .9\% up to $1.4 \%$ during the last 5 to 6 years (Skolverket, 2002) From 1992 to 2001 the number of students registered in schools and classrooms for students with severe learning disabilities . . . has increased by $67 \%$ (Rosenqvist, 2007, p. 67). This means that around 200,000 pupils in Sweden receive some kind of special educational support during the school year. Besides, as mentioned earlier, the Swedish society has become and will become increasingly multiethnic and multilingual. Reports indicate that the number of children and youth living in poverty has substantially increased over the last few years, and there is a significant increase in the number of homes where children speak a primary language other than Swedish. Students are at greater risk of needing special needs education services if they are poor and/or belong to a minority group.

Segregation at the metropolitan level creates an effective barrier between people. Suspiciousness, a mutual sense of outsiderness, and the construction of $\mathrm{We} / \mathrm{Them}$ boundaries can be nourished by the separation of social spaces. For many native-born citizens, places like Alby, Bergsjön, Fittja, Rågsved, Ronna, and Tensta surely sound as far away as Istanbul, Addis Ababa, Santiago, and Teheran. They are places one has never visited but whose names make their way through the media buzz, often associated with negative news...(T)he segregated city ought to be regarded as much the cause of social processes as the result of residential and moving decisions made by different groups (Andersson 1997, p.20).There are currently 6,579 people dwelling in Hammarkullen (a suburb of Göteborg). Seventy percent are of foreign background. Unemployment in the area is estimated at 90 percent (Holm, 1997). At the same time, unemployment among Somalis in Hammarkullen was put at 99 percent. (cited in Allan Pred, 2000).

Although the situation of immigrant children and youth in Sweden is not as extreme and dramatic as experienced by ethnic minority students as in, for instance, Israel and USA, some parallel patterns and aspects of the phenomena can be discerned even in Sweden (Berhanu, 2001). Some recent studies conducted in Sweden indicate overrepresentation of immigrant students out of all proportion to their numbers in special schools and classes (see, for instance, Bel Habib, 2001; Hahne Lundström, 2001; Lahdenperä, 1997; SOU, 1997, 2003). However, extensive and longitudinal studies have yet to be carried out in this specific problem area (see Rosenqvist, 2007) and there is a need for a coherent cumulative body of disproportionality research.

A few decades ago, special education was focused on addressing the special needs of physically, mentally, and socioemotionally affected segments of the student population. Currently, the needs to be addressed by special education have widened. And in fact as some sporadic Swedish statistics showed, two decades ago minority and immigrant students were slightly over-represented in special education programmes. The overrepresentation has not only persisted but has also 
dramatically increased (see the references in the paragraph above).

The over-representation is not a new phenomena. What is new is that new forms of exclusionary measures are taking place while the force of rhetoric toward inclusive measures is gaining substantial momentum in the pedagogical discourse. This Swedish experience is exactly similar to the practices in England as captured in the words of Florian and Rouse (2001): whilst the government calls for more inclusion and a greater recognition of diversity, it continues to promote social and educational policies that are not supportive of the development of inclusive schools. Indeed, many of the existing market place reforms ignore diversity and stress priorities that make it hard for schools to accept children who will not help them to meet their academic targets (p. 400). Although extensive studies have yet to be carried out, the already existing but sporadic studies (see, e.g., Bloom, 1999; Ilic-Stanisic, 2006; Källstigen, Riviera, \& Özmer, 1997; Källstigen, Ohlin, \& Setkie, 2002; Nilsen \& Ström, 2003; Skolverket, 2005a,b; SOU, 2003; Tideman, 2000) indicate that immigrant students are over-represented in special educational settings out of all proportion to their number. That observation is documented in big cities with large immigrant enclaves. My analysis of the phenomenon of over-representation is based on these limited materials.

General Factors: Sociocultural Problems, Budget Slash and Institutional Intransigence

In a recent report of the Swedish National Agency for Education (SOU, 2003; Skolverket, 2003) the over-representation of minority pupils in special schools has been outlined, and the indications are that the situation is alarming and there is cause for concern. The report based its analysis of the situation on two studies conducted in two big Swedish cities, Malmö and Göteborg. The report points out, among other things, that wrong/inappropriate assessments, classifications, and procedures infiltrate placement decisions (also Dagens Nyheter, 2007). This is in part due to the educational staff's lack of knowledge of the students' home, sociocultural, and language backgrounds. As the report pointed out, the most probable reason for their misplacements, misdiagnosis, may be linked to the difficult and traumatic experiences endured by the children and their families before arriving in Sweden. And, these experiences coupled with the new acculturation process might have curbed their normal school adjustment. Both the official report and a number of other studies including student theses (e. g., Bloom, 1999; Hahne Lundström, Nilsen \& Ström, 2003,2001; Ilic-Stanisic, 2006; Källstigen et al. 2002; Skolverket, 2005a ; Tideman, 2000) have pointed out that budget cuts or reduction could be one major factor that contributes to a general increase of students placed in special schools. This rise in special school placements has equally affected native Swedish students or ethnic Swedes. Tideman (2000) reminds us that these consistent budget cuts that have beset Sweden for the past 15 years have lessened/reduced tolerance for differences/diversity.

All the materials analysed here indicated that the groups whose representation has increased by over $80 \%$ in compulsory special schools are borderline cases, children with concentration difficulties, children with immigrant background, older students, and students with autism and autism related situations. The major reason ascribed to this increase is budget reduction. The cuts have brought about a rise in class size in ordinary schools, which in turn caused a decreased student-teacher ratio and a reduction in the numbers of special educators and special educational services at primary school level. This development takes place in parallel with the school authorities/politicians' demand to achieve the target goal designed for older students in higher grades, junior high school (6-9). The demand to fulfil the set goals, the quest for excellence, good test scores and examination results and a strong tendency for national systems of assessment and testing appear to have contributed to exclusionary pressures, ignoring issues of disadvantage, diversity, and equity.

According to the above cited studies, the decentralization process that took place in the 1990s giving local governments (municipalities) jurisdiction or full responsibilities to run schools is also said to have had an impact on the emergence of this dramatic over-representation. Accordingly, the phenomenon of over-representation also varies between municipalities. The local school authorities or schools have considerably varied evaluation parameters or procedures. Different districts have different interpretations of who is to be placed or entitled to be placed in special schools. There is generally locally designed evaluation practices of categorizing and labelling, the material basis of which is extremely questionable.

On the other hand, there are some who argue that the rise in the number of special school placements is a sign that placements in special classes/schools are dedramatized; that regular schools and special schools have come under a single school management (e.g., Nilsen \& Ström, 2003; Ilic-Stanisic, 2006; Bloom, 1999; Skolverket, 2005). Therefore, the rise is more a consequence of the closer working relationship between these entities than disengagement between them.

According to Bel Habib (2001), the discourse in Sweden about ethnic minority pupils swing between a collectivized and culturalised discourse as, on the one hand, expressed in the form of special needs children and, on the other, as in the 
form of pathological category, expressed as individual diagnosis tied to developmental delays. The author argues further that the school imposes its discipline-based exclusionary procedures and power techniques through turning structural/institutional-based teaching problems into cultural difference or individual focused handicap. This problem-shifting strategy (i.e., attaching the problem with the individual child or its culture or labelling procedures) has helped the school to avoid a critical evaluation of its own institutional practices and a change in its pedagogical and classroom management approach (Berhanu, 2005a). Lahdenperä's (1997) study with tens of Swedish teachers who work with immigrant /minority students strongly indicate that most of the teachers associate these students' educational difficulties with the individual students, and accordingly, the teachers' reaction to the problem is fundamentally based on how to correct the child or how to arrange compensatory mechanisms. Generally, my impressions that the studies conducted in Sweden are obviously not specific enough to explore questions of intent or that there is a purposeful discriminatory practice by which we mean blatantly discriminatory practices in policy or practice

\section{Family Factors, Parents' Educational Level and Power Distance}

My review of the literature shows a great deal of similarities between the experiences of other Western countries and Sweden with regard to the phenomenon of over-representation (Berhanu, 2001). The imbalance in power relationships between parents of students in special education arrangements and the school authorities is well documented (Gillbourn, 1990; Gillbourn \& Mirza, 2000; Losen \& Orfield, 2002). A similar study (Bel Habib, 2001) conducted in one city in Sweden in which there is a high concentration of immigrant families has documented the huge gap in power relationships between school authorities and these families. The families have enormous respect for school authorities and they do not argue with or confront school leaders. Many of these parents have a low level of formal education and have limited experiences as to how to deal with the authorities and usually genuinely trust the procedures that lead to placement decisions. The school tells them what is good for their children and parents accept the recommendations without questioning. The parents interviewed were not informed about the consequences of special educational placements and what these entailed for the future. It is not difficult to understand the reaction of parents and their feelings of powerlessness when the special educational evaluations are presented to them as a set of discreet decisions based on scientific analysis and assessment (Armstrong, 1995; Losen \&
Orfield, 2002; Galloway, Armstrong, \& Tomlinson, 1994).

\section{Evaluation and Diagnostics Procedures}

Surprisingly, the pattern observed elsewhere with regard to evaluation and diagnostic procedures bias is becoming increasingly visible in the Swedish context. Although the study I refer to here is based on one specific city, I fear that there is a tendency even in other parts of Sweden The very latest study (Rosenqvist, 2007) has, as its primary finding, documented this deficiency in evaluation and diagnostic procedures (also Dagens Nyheter, 2007). According to Bel Habib (2001), who used quantitative methods to map out the magnitude of the problem of over-representation, the majority of the Swedish students (native/white Swedes) in special schools have clear, visible, medically proven or concretized functional handicaps, whereas minority students who are assigned to these special schools, as the researcher distinguished from diagnosis and referral files, were categorised in diffused, vague, symptom-based and pedagogical-related terms such as concentration and behavioural problems, speech and language difficulties, unspecified poor talent or developmental retardation.

As is the case elsewhere (see, e.g., Losen \& Orfield, 2002; Dyson \& Gallannaugh, 2008; Harry \& Klinger, 2006) the special educational placement pattern for ethnic minority pupils is that these students are fairly represented (or in other words their representation is comparable to their number in the general society) in low incidence disabilities (e.g., visual, hearing, multiple and physical disabilities) and they are overrepresented in high incidence disabilities (e.g., emotional/behavioural disorder and learning disabilities). That means the observed overrepresentation is in subjective cognitive disability categories rather than in hard/visible disability categories (see Losen \& Orfield, 2002). Not surprisingly, in light of current experience in the United States, children from different social and ethnic groups found themselves disproportionately placed in these categories..... (Dyson \& Gallannaugh, 2008, p.36/37). Dyson \& Gallannaugh (2008) uses the term nonnormative categories instead of subjective cognitive disability though. Certainly, there is some evidence from Sweden to support this instance.

This observation testifies to the fact, as Foucault (1979, 1984) consistently argued elsewhere in his extensive writings, that institutions, in this case the schools, function to maintain and even advance the practice of normality and deviance through instruments of power and knowledge relations that not only exclude a segment of the student population but 
also serve as instruments to construct identities and labels such as students with special educational needs (also Allan, 1995).

A similar study conducted by Kari Hahne Lundström (2001, in SOU, 2003) on the overrepresentation of immigrant students in upper secondary special schools has come to a similar conclusion, namely that many of those students enrolled in the upper secondary school for students with intellectual disabilities do not have a diagnosed intellectual disability. In addition, immigrant students are diagnosed far less often than are their Swedish peers. In most cases, they have undergone one single test, which in turn determines or is used as argument for their school placement.

The tests are of an ability testing type, are standardized, and are usually administered on a one time basis. This is a phenomenon that most minority students go through in many western countries (see, e.g., Berhanu, 2005a,b; Brady et al. 1983; Gupta \& Coxhead, 1988; Hegarty, 1988). The tests are not culture free (Berhanu, 2007) and the evaluation does not sufficiently take into consideration the overall situation of the child. The test result tells very little about whether or not the child's inability to give correct answers has to do with his/her language skills or whether there is a sociocultural element in the way they understand and answer the question. It is a well known fact that these so called standardised testing programmes consistently discriminate against disadvantaged and vulnerable groups (see also Hillard, 1990).

The above study (Kari Hahne Lundström, 2001 in SOU, 2003), which focuses on the Göteborg area, shows that the proportion of students with ethnic backgrounds other than Swedish is $45 \%$, which is double that of their representation at national programmes in regular upper secondary school.

The reports analysed here, including a number of bachelor level student theses, clearly indicate that the evaluation reports upon which decisions were made to send students to special schools made do not provide a full picture of the problem that besets the individual student (e.g., Bel Habib, 2001). The students who are disproportionately represented never received a proper education support at primary schools and had limited participation in their overall educational process. The situation they were in, such as being in asylum shelters (immigrant reception centres) for many years, and the socialization/acculturation process during their temporary stay in the camps and life afterward may have been serious enough to have had severe repercussion on the children's' school adjustment. Lack of awareness of the complexities of these problems and their eventual outcomes plus a shortage of resources at primary school levels have aggravated the situation of these students. Their over-representation even in secondary special schools for young adults is therefore connected to this pitfall at the start of these students' schooling rather than the students' lack of cognitive ability or deficiency in their behavioural repertoire in any sense. As Gillborn and Youdell (2000, p.4) rightly pointed out, inequality is constructed:

We take the position that groups defined socially by class, gender, race, ethnicity and sexuality are inherently no less capable of educational participation and success. These groups are defined by social convention, not by inherent, fixed or natural differences.... The processes by which these constructed differences come to be related to inequalities in experience and outcome are complex, varied and stable. (quoted in Slee \& Allan, 2001)

The analysis indicates how the structure of schools as organisations creates special educational needs rather than differences or diversity between individual pupils. The lack of holistic, contextual, and ecological perspectives is visible because the measures used to send these children to special schools emerge from being entirely concerned only with pupils' cognitive, emotional, and pathological problems. To rectify this misguided practice, we need to, as Artiles (2003) correctly argued, transcend the traditional individualistic perspective and infuse a social justice dimension so that the improvement of educational experiences and life opportunities for historically marginalized students are of central importance (pp. 194-95).

A Swedish study by Sonnander and Emanuelsson (1993) clearly indicated how children who were not diagnosed and labelled have managed both school life and professional/work life much better than those students with similar ability level (begåvningsnivå) but who were defined as in need of special support. One question, therefore, is why special schools should ever exist if this is really true (see also Persson, 2001). Although more research is needed, there are already credible indications that these schools and other special educational arrangements do more harm than good. In particular, what is tragic here is the situation of students with immigrant background who were subjected to dubious procedures, classification, and evaluation criteria both at regular primary schools, which focus on their cultural and ethnic background, and special schools, which focus on individual pathology (Bel Habib, 2001; Rosenqvist, 2007). This is a fertile ground on which to create structural/institutional discrimination unless it is rectified immediately (Labi, 2001).

To summarise, both the statistical and qualitative analysis, compiled in Losen \& Orfield (2002, p. xviii) suggest some similar observations in the U.S.A. as in Sweden, although the statistical figures and the magnitude of the problem between these two countries vary considerably. These American studies suggest that racial, ethnic, and gender differences in special educational 
placements are due to many complex interacting factors, including unconscious racial bias on the part of school authorities, large resource inequalities that run along lines of race and class, unjustifiable reliance on IQ and other evaluation tools, educators' inappropriate responses to the pressures of high-stakes testing, and power differentials between minority parents and school officials.

\section{Discussion and Conclusion}

Throughout the different parts in this paper, there are threads that are well represented in the current tapestry of ideas associated with postmodern theorising on multiplicity of voices, the multiply constituted subject, and the social and historical construction of ethnicity and difference and its role in the distribution of power. What is too often missing in research in education is an integrated analysis. Researchers usually focus on one or the other component of a complex educational issue and give the erroneous impression that differences in social performance are due to differential cognitive differences among groups or individuals that are due to one or two factors. Some of the usual ones are linguistic factors, cultural deficits, cultural differences, and parent-child dyads (Berhanu, 2005a,b; 2006, 2007). What is often ignored are the effects of power discourse, institutional intransigence, teacher-student relationship, pedagogy, classroom interactions, and the dispositions that young people, for a whole variety of reasons, bring to their learning. The evidence produced by this work supports the conclusion that separate analysis of any one of these factors can provide neither a full picture nor an adequate explanation of problems related to something as complex as differential patterns of learning or disproportionality.

In this study, I adopted Vygotsky's theory as a general framework. That is, cognitive development (learning) is a product of interaction with others in the presence of socio-historically developed tools that mediate intellectual activity. This is also in line with the philosophy of inclusive education in which the emphasis is on learning together within the regular educational framework. Vygotsky underlines the role of culture and social interaction as opposed to just interaction (as in Piaget) in the development of children's cognitive processes. This belief in the role of social interaction led Vygotsky to formulate the zone of proximal development (ZPD), a concept of significant educational and instructional implications. The ZPD as a metaphor or construct has drawn great interest in the research community because of its dynamic developmental element that focuses on what a child can achieve with assistance of a more capable adult or peer. One of the implications of the ZPD in instruction and educational practices is that the conventional practices such as IQ tests, chronological or agegraded organisation or learning environments, competition, and speed cannot be congenial to all diverse cultural groups. In cultural-historical theory, developmental stages simply index age norms in a given sociocultural space and time. Education aimed at where the student is at takes on new meaning in societies with increasing ethnic diversity (Portes, 1996; Moll, 1990).

Although in the works of Vygotsky and his followers, institutional/social structural domains are mentioned as having significant impact on children's dispositions towards their school performance, the process under which the impact is felt (power discourses, the subtle workings of institutional culture, which is intricately bound with the wider political, social, and economic as well as cultural meaning systems and moral, values) have not been made explicit. Thus in this work an attempt has been made to identify the influences of the institutional culture of schools that distort or retard learning progress. These include (a) an absence of knowledge, understanding and sensitivity on the part of schools to how students from different cultural backgrounds learn; (b) the application of unreliable (wrong) assessment (evaluation) procedures and criteria for referral and placements; (c) the lack of culturally sensitive diagnostic tools; and (d) the static nature of the tests, including the cultural bias embedded in the tests. The problem surrounding the overrepresentation of ethnic minorities in special educational arrangements in Sweden is complex, and some of the evidence presented here also points to problems surrounding the home environment, including poverty; sociocultural related problems, family factors, and language problems; the lack of parental participation in decision making and the huge power distance between parents and school authority; institutional intransigence and prejudices; and large resource inequalities that run along lines of race and class. Similarly, Dyson \& Gallannaugh (2008) argued, based on a very recent research on proportionality in England, that ....although the identification of children as having special educational needs may result most immediately from the construction of difference at the school and teacher levels, that construction is itself a response to educational and social inequalities. It follows that a proper understanding of disproportionality, capable of generating effective means of combating it, requires an analysis not only of processes of construction but also of the underlying processes and structures through which social and educational inequality are produced (p. 43).

Barbara Rogoff's statements in the concluding chapter of her widely acclaimed book (1990) parallel my observations and analysis. She 
underscores the problems encountered by students who are grounded in one cultural system while attempting to function in another which, if not simply indifferent, provides no recognition that a huge cultural divide exists:

If differences in values and practices are handled with respect, children can benefit from learning new cultural systems while maintaining their "home" approach. Unfortunately, children dealing with two cultural systems often face a less supportive contact between them. The dominant culture may be seen as competing with that of the home culture, with a goal of eradicating the features of the home culture rather than using them to build an understanding of the new approach. This eradication mentality, stemming from differences in status between two cultural approaches, may make it rare for children to have the opportunity to become bicultural (an opportunity that would be advantageous for majority as well as minority children). Rather, many children end up not becoming skilled in any culture, whether because their home culture is devalued and potential links are not exploited to help them learn the ways of the dominant culture, or because their home culture itself suffers such economic stress that the culture looses its strength and coherence, as may be the case for many very poor children. (pp.201202)

Bauman (1992, 1998, 2001) argues eloquently that globalisation has produced a shift from social rights to competition, productivity, standardisation, and efficiency, and a shift from public to private and from social responsibility to individual (or family) responsibility. As a process, globalisation is not linear, but contradictory and contested. Its impacts are unequal and differ on the basis of regions, classes, and people. The neo-liberal economy is dominating the world especially after the end of the cold war, and its particular form of capitalism is characterised by deregulating markets, reducing or changing the role of the state and most importantly, reducing social expenditure, including expenditure on education. This phenomenon has also been witnessed in the past 15 years even in Sweden in tandem with rising unemployment, issues of security, alienation, marginalisation, and exclusion, creating a discourse of resentment along the lines of them versus us. This trend is inextricably intertwined with the dramatic increase of children and young people who are referred to special schools for intellectually disabled pupils (Särskolan). In this connection, the drive to improve standards and set a strict grading system is one area of problem that constructs special educational needs students as failing Yet at the same time, there is a drive to educate all students within mainstream schooling (i.e., inclusive education as witnessed already in post-war Swedish history). The standards agenda that emerged in the 1990s because of the changes in the political climate, and the resulting impact on school policy, is one of the most insurmountable barriers to learning for special education needs students.

\section{REFERENCES}

Allan, J. (1995). Pupils with Special Educational Needs in Mainstream Schools: A Foucauldian Analysis of Discourses. University of Stirling, Department of Education.

Andersson, R. (1997). "Svensk glesa bostadsområden," Invandrare och Minoriteter, No.2: 19-24. (In Swedish)

Armstrong, D. (1995). Power and partnership in education: Parents, children and special educational needs. London: Routledge.

Artiles, A. J. (2003). Special education's changing identity: Paradoxes and dilemmas in views of culture and space. Harvard Educational Review, 73(2), 164-202.

Barton, L. (1997). Inclusive education: Romantic, subversive or realistic? International Journal of Inclusive Education, 1(3), 231-242.

Bauman, Z. (1992) Intimations of post modernity. London: Routledge.

Bauman, Z. (1998) Globalisation: The human consequences. Cambridge, UK: Polity Press.

Bauman, Z. (2001). The individualised society. Cambridge, UK: Polity Press.

Bel Habib, I. (2001). Elever med invandrarbakgrund i särskolan: specialpedagogik eller disciplinär makt.

Kristianstad: Högskolan i Kristianstad. Enheten för kompetensutveckling

Berhanu, G. (2001). Learning - In - Context. An Ethnographic Investigation of Mediated Learning Experiences

Among Ethiopian Jews In Israel. Göteborg: Acta Universitatis Gothoburgensis, Göteborg Studies in Educational Sciences 166.

Berhanu, G. (2005a). Normality, deviance, identity, cultural tracking and school achievement: The case of

Ethiopian Jews in Israel. Scandinavian Journal of Educational Research, 49(1), 51-82.

Berhanu, G. (2005b). Indigenous conception of intelligence, ideal child, and ideal parenting among Ethiopiaan

Jews in Israel. Journal of Cognitive Education and Psychology, 5(1), 47- 71.

Berhanu, G. (2006). Parenting (parental attitude), child development, and modalities of child-parent interactions:

Sayings, proverbs, and maxims of Ethiopian Jews in Israel. Journal of Cognitive Education and Psychology, 5(3), 266287.

Berhanu, G. (2007). Black intellectual genocide: An essay review of IQ and the Wealth of Nations. Education Review, 10(6).

Bloom, A. (1999). Särskilda elever. Om barn i särskolan bedömningsgrunder, ställningstagande och erfarenheter. FoU- Rapport 199:28. Stockholm: AWJ Kunskapsföretaget AB.

Brady, P. M., Manni, J. L., \& Winnikur, D. W. (1983). 'Implications of ethnic disproportion in programs for the educable mentally retarded'. In Journal of Special Education, 17, 3, 295-302. 
CEEP (2004, Nov.) Moving towards equity: Addressing disproportionality in special education in Indiana. Center for Evaluation and Education Policy, Indiana University, School of Education.

Clark, C., Dyson, A., \& Millward, A. (1995). Towards Inclusive Schools. London: David Fulton.

Coard, B. (1971). How the West Indian children is made educationally subnormal in the British Educational system. London: New Beacon.

Dagens Nyheter (2007). Invadrarelever skrivs felaktigt in i särskolan Tuesady June 12-2007. (The Swedish Daily).

Dyson, A. \& Gallannaugh, F. (2008). Disproportionality in Special Needs Education in England The journal of Special Education, 42(1), 36-46.

Emanuelsson, I. (1998). Integration and segregation - inclusion and exclusion. International Journal of

Educational Research, 29, 95- 105.

Emanuelsson, I. (2000a). Är det normalt att vara godkänd? I KRUT, no. 99, 3/2000. (In Swedish)

Emanuelsson, I. (2000b). Specialpedagogen på marknaden. I Att Undervisa, 5-2000, pp. 6-9. (In Swedish)

Emanuelsson, I., Haug, P., \& Persson, B. (2005). Inclusive education in some Western European countries: Different policy rhetorics and school reality. In D. Mitchell (Ed.).,Contextualising inclusive education: Old and new paradigms. London: Routledge.

Florian, L., \& Rouse, M. (2001). Inclusive practice in English secondary schools: Lessons learned. Cambridge Journal of Education, 31(3), 399-412.

Foucault, M. (1979). On governmentality. Ideology and Consciousness, 6, 5-21.

Foucault, M. (1984). On the genealogy of ethics: An overview of work in progress. In P.l Rabinow (Ed.), The Foucault Reader. London: Peregrine.

Galloway, D., Armstrong, D., \& Tomlinson, S. (1994). The assessment of special educational needs - Whose

problems? London: Longman.

Giddens, A. (1990). The contradictions of modernity. Cambridge: Polity Press.

Gergen, K. (2001). Socila construction in context. Thousand Oaks, CA: Sage.

Gillborn, D. (1990). Race, ethnicity and education: Teaching and learning in multiethnic schools. London: UnwinHyman.

Gillborn, D., \& Gipps (1996). Recent research on the achievements of ethnic minority pupils. London: Her Majesty's Stationary Office.

Gillborn, D., \& Mirza, H. (2000). Educational inequality. Mapping race, class and gender. London: OFSTED.

Gillborn, D., \& Youdell, D. (2000). Rationing education: Policy, practice, reform and equity. Buckingham, Open University Press.

Gupta, R. M., \& Coxhead, P. (Eds.). (1988). Cultural diversity and learning efficiency: Recent developments in assessment. Macmillan: London.

Hacking, I. (1999). The social construction of what? Cambridge, MA.: Harvard University Press.

Hahne Lundström, K. (2001). Intagningskriterier till gymnasiesärskolan i Göteborg. Projektarbete vid Arbetslivsinstitutets Företagsläkarutbildning 2000/2001
Harry, B., \& Klinger, J.K. (2006). Why are so many minority students in special education? Understanding race and disability in schools. New York: Teachers College Press.

Hegarty, S. (1988). Learning ability and psychometric practice. In R. M. Gupta \& P. Coxhead (Eds.), Cultural diversity and learning efficiency: Recent developments in assessment (pp. 22- 38). London: Macmillan.

Hillard, A. (1990). Misunderstanding and testing intelligence. In J. I. Goodland \& P. Keating (Eds.), Access to knowledge: an agenda for our nation's schools (pp. 145-158). New York, NY: The College Board.

Holm, M. (1997). “På jakt efter endräkt.” Dagens nyheter, June 20, 1997. (In Swedish)

Ilic-Stanisic T. (2006). Vem placeras i särskolan. En intervjustudie om hur placering i särskolan går till, med särskilt fokus på elever med invandrarbakgrund. Examensarbete 10 p. Göteborgs Universitet. (In Swedish)

Källstigen, G., Riviera, T., Özmer, D. (1997) Att inte vara stöpt i samma form. Om kulturmöten och funktionshinder. SIT. Läromedel. Örebro. (In Swedish)

Källstigen, G., Ohlin, C., \& Setkic, M. (2002): Mötesplats: Sverige. Funktionshinder och kultur möte. Högskolan i Kristianstad.

Labi, A. (2001). A class apart: A segregated school raised questions about the limits of Swedish Liberalism. Time, Feb, 19, 2001, pp. 22- 23.

Lahdenperä, P. (1997). Invandrarbakgrund eller skolsvårigheter?: En textanalytisk studie av åtgärdsprogram för elever med invandrarbakgrund. Stockholm: HLS, 1997, Studies in Educational Sciences, 7. (In Swedish)

Leijon, S., \& Omanovic, V. ( 2001). Mångfaldens mångfaldolika sätt at se på och leda olikheter. FE-rapprt 2001-381. (In Swedish)

Losen, D. J. \& Orfield, G. (2002). Racial inequity in special education. Cambridge, MA: Harvard Education Press.

Moll, L. C. (1990). Vygotsky and education: Instructional implications and applications of socio historical psychology. Cambridge, UK: Cambridge University Press.

Nilholm, C., \& Björck-Åkesson, E. (Eds.) (2007).Reflektioner kring specialpedagogik- sex professorer om forskningsområdet och forskningsfronterna. Stockholm: Vetenskapsrådet. (In Swedish)

Nilsen, C., \& Ström, A. (2003). Fler I särskolan: En qualitative undersökning över orsakarna till den $80 \%$

ökningen I särskolan mellan läsåren 1992/1993 - 2002/03. Pedagogiskt/didaktisk Examensarbete (C-uppsats): Göteborg University, Lärarprogrammet. (In Swedish)

Obiakor, F. E. (1994). The eight-step multicultural approach: Learning and teaching with a smile. Daybook, IA: Candle/Hunt.

Obiakor, F. E., \& Utley, C. A. (1997, Spring). Rethinking preservice preparation for teachers in the learning disabilities field: Workable multicultural strategies. Learning Disabilities Quarterly, 12, 100-106.

OFSTED (1999). Raising the attainment of minority ethnic pupils: School and LEA Responses (London: Ofsted)

Oswald, D., Coutinho, M., \& Best, A. (2000). Community and school predictors of over representation of minority students in special education. Paper presented at the Harvard University Civil Rights Project Conference on Minority Issues in Special Education, Cambridge, MA. 
Persson, B. (1998). Den motsägelsefulla specialpedagogiken. [The contradictions of special education]. Special Educational Reports no.11. Doctoral thesis. Göteborg University, Department of Education. (In Swedish)

Persson, B. (2001). Special education, academic self-concept and achievement: Profile differences between six groups of students. Journal of Research in Special Educational Needs, vol. 1, No. 2 June 2001.

Persson. B. (2002). Åtgärdsprogram i grundskolan. Förekomst, innehåll och användning. [Individual Educational Plans in the Swedish compulsory School. Prevalence, content and usage]. Rapport till Skolverket. (In Swedish)

Portes, P. R. (1996). Ethnicity and culture in educational psychology. In D. C. Berliner \& R. C. Calfee (Eds.), Handbook of educational psychology (pp. 331- 357). New York, NY: Macmillan.

Pred, A. (2000). Even in Sweden: Racism, racialised spaces and the popular geographical margination. California, University of California Press.

Raveaud, M. (2003). Ethnic minorities and 'enfants issus de l'immigration': The social construction of difference through national education policy in England and France. Paper presented at the RAPPE (Network for Crossdisciplinary Analysis of Education policy). Seminar on governance, regulation and equity in European Education Systems, London Institute of Education, 20-21 March 2003).

Rogoff, B. (1990). Apprenticeship in thinking: Cognitive development in social context. New York, NY: Oxford University Press.

Rosenqvist, J. (2007 Specialpedagogik i mångfaldens Sverige: Om elever med annan etnisk bakgrund än svensk $i$ särskolan (Ett samarbetsprojekt mellan Specialpedagogiska institutet och Högskolan Kristianstad (HKr), Specialpedagogiska institutet (Dnr 14-06/2428). (In Swedish)

Skolverket. (1998). Elever i behov av särskilt stöd. Stockholm: Skolverket. (In Swedish)

Skolverket. (2002). Barnomsorg, skola och vuxenutbildning $i$ siffror 2002 del 2. Rapport 214. Stockholm: Skolverket. (In Swedish)

Skolverket. (2003). Kartläggning av åtgärdsprogram och särskilt stöd i grundskolan Stockholm: skolverket. (In Swedish)

Skolverket. (2004). Elever med utländsk bakgrund. Dnr 75 2004: 545: Stockholm: Skolverket. (In Swedish)

Skolverket. (2005a) Den individuella utvecklingsplanen. Allmänna råd och kommentarer. Best nr:05:920 Stockholm: Fritzes kundservice, http://www.skolverket.se/. (In Swedish)

Skolverket. (2005b). Kvalitet i förskolan. Allmänna råd och kommentarer. Stockholm: Fritzes kundservice, http://www.skolverket.se/. (In Swedish)

Skrtic, T. (1991). Behind Special Education: A critical analysis of professional culture and school organization. Denver, CO: Love.

Skrtic, T. (Ed.). (1995). Disability and democracy: Reconstructing (special) education for postmodernity. New York: Teachers College Press.

Slee, R., \& Allan, J. (2001) Excluding the Included: A Reconsideration of inclusive education. International Studies in Sociology of Education, 11(2), 173-191.

Sonnander, K. \& Emanuelsson, I. (1993). Pupils with mild mental retardation in regular Swedish schools: Prevalence, objective characterstics and subjective evaluation American Journal of Mental Retardation, 97(6):692-701.

SOU (1997:121). Skolfrågor. Om skola i en tid. Slut betänkande av skolkommittén. Stockholm: Utbildningsdepartementet. (In Swedish)

SOU 1999:63. Att lära och leda. En lärarutbildning för samverkan och utbildning. Stockholm: Utbildningsdepartementet. (In Swedish)

SOU (2003:35). För den jag är. Om utbildning och utvecklingstörning. Stockholm: Skolverket. (In Swedish) Statistics Sweden (2004) Statistisk Årsbok 2004 (Statistic Yearbook 2004).

Tideman, M. (2000). Normalisering och kategorisering. Sollentuna: Johansson \& Skyttmoförlag AB. (In Swedish)

Thomas, G., \& Loxley, A. (2001). Deconstructing special education and constructing inclusion. Buckingham: Open University.

Vallet, L.A., \& Caille, J.P. (1995). Les carriéres scolaires au collége des éléves étrangers ou issus de l'immigration, Education et formations, 40, 5-14. (In French)

Valsiner, J., \& Van der Veer, R. (2000). The social mind. Construction of the idea. Cambridge, UK: Cambridge University Press.

van Zanten, A. (1997). Schooling immigrants in France in the 1990s: Success or failure of the Republican Model of integration? Anthropology and Education Quarterly, 28(3), 351-374.

Vygotsky, L. S. (1934). Thought and language. Cambridge, MA: MIT Press.

Vygotsky, L. S. (1978). Mind in society: The development of higher psychological processes. Cambridge, MA: Harvard University Press.

Wenger, E. (1998). Communities of practice. Learning, meaning, and identity. Cambridge, MA: Harvard University Press.

Willis, P. (2000). The ethnographic imagination. Cambridge, UK: Polity Press. 